\title{
Dental Education and Care for Underserved Patients: An Analysis of Students' Intentions and Alumni Behavior
}

\author{
Carlos S. Smith, B.S.; Todd V. Ester, D.D.S., M.S.; Marita Rohr Inglehart, Dr. phil. habil. \\ Abstract: The U.S. surgeon general's report on oral health stressed the importance of providing dental care to underserved \\ patients. The objectives of this study were to explore a) dental students' intentions and dentists' behavior concerning treating \\ underserved patients, b) their perceptions of their education concerning these patients, and c) the relationship between dental \\ education and their attitudes and behavior. Data were collected from 328 dental students (response rate: 77.5 percent) and 234 \\ alumni (response rate: 43.7 percent). Only 67.4 percent of the students and 38 percent of the alumni indicated that their education \\ had prepared them well to treat patients from different socioeconomic backgrounds; 71.3 percent of students and 55.2 percent of \\ alumni responded that they had been well educated to treat patients from different ethnic/racial groups. The findings showed a \\ positive relationship between the degree of curriculum focus on the importance of treating patients from all aspects of society and \\ students' and alumni intentions to provide inclusive patient care to patients from diverse backgrounds. The more students agreed \\ that their dental education had prepared them well to treat patients from different ethnic backgrounds, the more likely they were \\ to report that they intended to treat these patients $(\mathrm{r}=.12 ; \mathrm{p}=.033)$. In a similar manner, the more the alumni agreed that their \\ dental education had prepared them well to treat patients in different communities, the more likely they were to treat patients \\ from different socioeconomic backgrounds $(\mathrm{r}=.18 ; \mathrm{p}=.009)$. In conclusion, these findings showed that access to oral health care \\ for underserved patients could potentially be increased if dental students were more overtly educated about the importance of \\ treating patients from all segments of society.
}

Mr. Smith is a third-year dental student; Dr. Ester is Director, Office of Multicultural Affairs, School of Dentistry; and Dr. Inglehart is Associate Professor, Department of Periodontics and Oral Medicine, School of Dentistry and Department of Psychology, College of Literature, Science, and Arts - all at the University of Michigan. Direct correspondence and requests for reprints to Dr. Marita Rohr Inglehart, Department of Periodontics and Oral Medicine, School of Dentistry, University of Michigan, Ann Arbor, MI 48109-1078; 734-763-8073 phone; 734-763-5503 fax; mri@umich.edu.

This study was supported by an AADR Student Research Fellowship (2004) to the first author.

Key words: underserved patients, access to care, dental education, professional behavior, professional attitudes

Submitted for publication 9/24/05; accepted 12/20/05

$\mathrm{I}$ n the year 2000, the U.S. surgeon general's report on oral health clearly described the inequities and disparities that affected those U.S. citizens least able to muster the resources to achieve optimal oral health. ${ }^{1}$ Persons with the worst oral health were found among the poor of all ages. Members of racial and ethnic minority groups also experienced a disproportionate level of oral health problems. Individuals who were medically compromised or who had disabilities were also at a greater risk for oral diseases. ${ }^{1}$ These patient groups with significantly higher levels of oral disease also encountered more severe problems with gaining access to dental care. ${ }^{2}$ A recent report by the Sullivan Commission ${ }^{3}$ documented clearly that additional dental care providers are needed to address the disparities in oral health

problems based on race/ethnicity. Dental schools could play an important role in this situation ${ }^{4}$ and clearly have a societal obligation to educate the workforce of the future in such a way that health care disparities and access to care problems cannot only be reduced but ultimately eliminated. ${ }^{5}$ An important question in this context is whether dental education can truly affect whether dentists will treat underserved populations after their graduation from dental school programs. This study therefore explored the role of dental education in preparing providers to serve underserved patients. The study had three objectives: 1) to determine the percentage of dental students in one dental school who intended to treat underserved patients in their future professional lives and the percentage of alumni of the same den- 
tal school who treated underserved patients; 2) to determine how well both dental students and alumni thought their dental education had prepared them for providing care for different groups of underserved patients; and 3) to determine the effect of dental education on attitudes and behavior concerning the treatment of underserved patients.

The burden of poor oral health is disproportionately borne by individuals from lower socioeconomic backgrounds at each life stage as well as by patients who are vulnerable because of poor general health. ${ }^{1}$ Profound and consequential oral health disparities are due to socioeconomic factors, age, sex, race/ethnicity, and/or medical/ability status. Access to care makes a huge difference in the lives of these individuals. Disparities have also been found in the number of oral health professionals from different ethnic/racial backgrounds. ${ }^{3}$ Throughout history, the number of underrepresented minorities in the oral health professions has been disproportionate to the representation of their ethnic/racial groups in the U.S. population at large; this pattern is still true today. Patients tend to select health care providers from their own racial background. ${ }^{3}$ Thus, patients from underrepresented minority groups who do not have a minority provider accessible to them may neglect basic oral health care needs. ${ }^{6}$ The first questions in our study therefore were what percentage of alumni provided care for different groups of underserved patients and what percentage of dental students intended to provide care for these populations.

Dentists' educational backgrounds concerning underserved populations may affect their decision making concerning the treatment of underserved populations. The dentists' educational background, their experiences in dental school, their community service activities, and their participation in continuing education courses may influence decisions about treating underserved patients. ${ }^{7}$ Several studies have demonstrated, for example, that dentists' lack of education concerning providing services for patients with special needs was significantly correlated with their willingness to actually treat these patients. ${ }^{8-10}$ Lack of educational preparation was correlated with a lack of confidence when providing care for these patients, and this lack of confidence ultimately affected the dentists' willingness to treat these patients. ${ }^{11}$ A study by Novak et al. found that the perceived importance of including diversity-specific content in the dental curriculum had moderately positive correlations with students' perceptions of their competency or ability to serve and work with diverse populations. ${ }^{12}$ In con- sideration of these findings, it was predicted that the better students and alumni felt prepared by their dental education to treat various groups of underserved patients, the greater their willingness would be to treat these patients.

An additional focus was to analyze student and alumni attitudes concerning treating underserved patients and to assess the impact of dental education on shaping these attitudes. Research showed that providers' beliefs about human rights and their personal values were incentives for providing care to underserved patients. ${ }^{13}$ The significance of personal beliefs was also demonstrated in a study with alumni dentists affiliated with the National Health Service Corps. This research conducted by Mofidi et al. showed that altruistic motivations were a positive predictor of the number of years working with underserved populations in the National Health Service Corps. ${ }^{14}$ The importance of negative attitudes was also documented in a study of dentists' willingness to serve special needs patients. This research showed that negative attitudes toward patients with special needs affected dentists' willingness to provide care for these patients. ${ }^{15}$ The results of these studies $^{12-15}$ indicate that it is important to investigate the relationship between dentists' attitudes and beliefs and the dental education they received concerning serving different groups of underserved patients.

In summary, the overall goal of this study was to explore the impact of dental education on dental students' attitudes and intentions to treat underserved patients in their future professional lives and on practicing dentists' attitudes and actual behavior concerning treating underserved patients.

\section{Methods}

This study was approved by the Institutional Review Board (IRB) for the Health Sciences at the University of Michigan (\#H04-00004381). Data were collected in the spring of 2004 from dental students enrolled during the academic year 2003-04 at a midwestern dental school and dental alumni of the same institution from the graduating classes of 1980 , 1985, 1990, 1995, and 2000.

The student survey was distributed to students in all four dental school classes in early April 2004. Three hundred twenty-eight of the 423 students responded for an overall response rate of 77.5 percent (first-year class: 67.8 percent; second-year class: 92.1 percent; third-year class: 75.9 percent; fourth-year 
class: 75.2 percent). Approximately 51 percent of the respondents were male, and 49 percent were female. The students ranged in age from twenty to forty years of age (mean $=25.22$ years). The ethnicity/race of the dental students was predominantly white $(\mathrm{N}=204$; 66.0 percent), with forty-four Asian/Asian American students (14.2 percent), twenty-eight African American students (9.1 percent), thirteen students from India or Pakistan (4.2 percent), nine Hispanic students (2.9 percent), and five Middle Eastern students (1.6 percent).

The alumni survey was mailed to all alumni of the five graduating dental school classes in the years 1980, 1985, 1990, 1995, and 2000. Overall, 234 of the 535 dental alumni responded for a response rate of 43.7 percent (year 2000 graduates: 41.3 percent; year 1995 graduates: 36.6 percent; year 1990 graduates: 48.6 percent; year 1985 graduates: 37.9 percent; year 1980 graduates: 52.9 percent). Approximately 67 percent of the respondents were male, and 33 percent were female. The alumni ranged from twenty-eight to sixty-four years of age. The ethnicity/ race of the dental alumni was predominately white $(\mathrm{N}=200 ; 87.7$ percent), with twelve Asian/Asian American alumni (5.3 percent), ten African American alumni (4.4 percent), three Hispanic alumni (1.3 percent), and three Middle Eastern alumni (1.3 percent). Six respondents did not provide information about their ethnicity/race.

The participating dental students volunteered to respond to the survey when they were approached at the end of a regularly scheduled class. The students were instructed to answer honestly. The average time to complete the survey was approximately seven minutes. All students were informed that participation was voluntary and that the refusal to participate would not affect their grade. No identifying information was gathered. The students returned their completed surveys in sealed envelopes to the researchers. The dental alumni volunteered to respond to a mailed survey that was introduced to them in a cover letter of support written by the dean of the dental school. A stamped, self-addressed return envelope was included in the mailing.

The dental students and dental alumni responded to a self-administered survey that included questions concerning their personal background, educational experiences, practice characteristics, and attitudes and values. The majority of these questions had been developed and used in the study by Dao et al. ${ }^{10}$ Background information was collected concerning the respondents' gender, ethnicity/race, age, the place where they grew up, how their family paid for dental treatment when they were a child, their family's socioeconomic background, their status as a dental student/dental alumni, the year enrolled in the program, or the year graduated. Information was also collected on the dental students' previous and current volunteer activities and the alumni dentists' level of indebtedness at the completion of their dental education.

Personal background questions asked how much personal contact the respondents had with socioeconomically disadvantaged persons, patients on Medicaid, unemployed persons, persons from different ethnic/racial backgrounds, person with disabilities, and persons from different locations. Concerning the concept "socioeconomically disadvantaged persons," no definition was provided for the respondents. Instead, it was assumed that the respondents would have similar definitions of the concept.

Educational information was collected concerning the respondents' perceptions of how well they had been prepared by the dental school in various areas of their professional lives, such as treating patients from socioeconomically disadvantaged backgrounds and from different ethnic/racial groups, treating patients with disabilities, treating patients in different types of communities, gaining insight into the barriers to oral health care, and becoming aware of problems related to oral health. As shown in the legends to the tables, the answers were given on a 5point rating scale.

Several questions addressed the respondents' future and actual professional activities such as providing care for diverse patient populations, treating patients from all socioeconomic backgrounds, treating patients with disabilities, treating underserved patients, volunteering services to underserved patients, addressing community needs, making a positive difference on public issues, and collaborating with people of diverse backgrounds and interests. In addition, Likert-style items assessing the respondents' attitudes and values concerning the treatment of underserved patients were included. The statements provided were concerned, for example, with how much the respondents valued treating patients, making a difference in the lives of others, and interacting with patients from different backgrounds. The wording of these items is included in the tables. A Likert scale answering format was used with the answering scale ranging from $1=$ strongly disagree to $5=$ strongly agree. 


\section{Results}

The first objective was to investigate what percentage of a) dental students intended to serve underserved patients in the future and b) dental alumni actually treated these patients in their practices. As can be seen in Table 1, over 50 percent of the dental students planned to treat a diverse patient population (55.1 percent), to treat patients from all socioeconomic backgrounds (55.1 percent), and to volunteer their services to underserved patients (68.3 percent). Their responses concerning attitudes/values related to these matters were overwhelmingly positive: 71.4 percent of the students agreed with the statement that they will use their abilities to address

Table 1. Frequencies/percentages of students and alumni who intended to/actually treated patients from different underserved patient groups

Students: In my future professional life

Dentists: In my professional life

I treat a diverse patient population.

Stu

Disagree*

Neutral**

$\begin{array}{ccc}\text { Agree }^{* * *} & \mathrm{p} & \text { mean } \\ 178 & .000 & 3.57 \\ 55.1 \% & & \\ 101 & & 3.31 \\ 44.1 \% & & (.005)\end{array}$

I treat patients from all socioeconomic backgrounds.

I treat patients with disabilities.
I treat underserved patients.
I volunteer my services to underserved
patients.

Students

34
$10.5 \%$

$\begin{array}{ll}\text { Dentists } & 39 \\ & 17.3 \%\end{array}$

$\begin{array}{ll}\text { Students } & 37 \\ & 11.4 \% \\ \text { Dentists } & 54\end{array}$

$\begin{array}{ll}\text { Dentists } & 54 \\ & 23.6 \%\end{array}$

Students

$$
42
$$

Dentists

$12.9 \%$

92

$40.5 \%$

$\begin{array}{ll}\text { Students } & 18 \\ & 5.5 \% \\ \text { Dentists } & 81 \\ & 36.0 \%\end{array}$

I use my abilities to address community needs.

$\begin{array}{ll}\text { Students } & 15 \\ & 4.6 \% \\ \text { Dentists } & 70 \\ & 30.9 \%\end{array}$

I make a positive difference on public issues.

$\begin{array}{lcllcc}\text { Students } & 16 & 90 & 219 & .000 & 3.79 \\ & 4.9 \% & 27.7 \% & 67.4 \% & & \\ \text { Dentists } & 80 & 77 & 70 & & 2.93 \\ & 35.3 \% & 33.9 \% & 30.8 \% & & (.000) \\ & & & & & \\ \text { Students } & 14 & 88 & 223 & .000 & 3.84 \\ & 4.3 \% & 27.1 \% & 68.6 \% & & \\ \text { Dentists } & 43 & 67 & 120 & & 3.47 \\ & 18.7 \% & 29.1 \% & 52.2 \% & & (.000)\end{array}$

I like opportunities to collaborate with people of diverse backgrounds and interests.

106
$32.8 \%$
70
$30.6 \%$

111
$34.4 \%$
51
$22.6 \%$
136
$41.8 \%$
47
$20.5 \%$
120
$37.0 \%$
51
$22.5 \%$

178
$55.1 \%$
136
$60.2 \%$
152
$46.8 \%$
128
$55.9 \%$
$162 \%$
$50.0 \%$
84
$37.0 \%$

.000

3.56

3.64

(.353)

3.45

3.55

(.230)

3.49

3.06

(.000)

85
$26.2 \%$
49
$21.8 \%$
222
$68.3 \%$
95

.000

3.89

3.09

(.000)

78
$24.0 \%$
73

232

$71.4 \%$

.000

3.86

84

3.05

(.000)

$37.1 \%$

(.000)

The answers were given on a 5-point answer scale with 1 being "disagree strongly" and 5 being "agree strongly."

*The frequencies of answers of the respondents who answered with " 1 " or " 2 " were summed up in the column "Disagree."

**The frequencies of answers of the respondents who responded with "3" are presented in the column entitled "Neutral."

***The frequencies of answers of the respondents who answered with " 4 " or " 5 " were summed up in the column entitled

"Agree." 
community needs, and 67.4 percent believed that they will make a positive difference on public issues. Approximately 69 percent of students indicated that they were willing to collaborate with people of diverse backgrounds and interests (68.6 percent). However, only 46.8 percent of the students indicated that they planned to treat patients with disabilities.

Next we compared the self-reported actual behavior of alumni to the students' intentions. Compared to the students, a lower percentage of alumni actually provided care for diverse patients (students: 55.1 percent vs. alumni: 44.1 percent; $\mathrm{p}<.001)$; treated underserved patients (students: 50.0 percent vs. alumni: 37.0 percent; $p<.001$ ); volunteered their services to underserved patients (students: 68.3 percent vs. alumni: 42.2 percent; $\mathrm{p}<.001$ ); used their abilities to address community needs (students: 71.4 percent vs. alumni: 37.1 percent; $\mathrm{p}<.001$ ); made a positive difference on public issues (students: 67.4 percent vs. alumni: 30.8 percent; $\mathrm{p}<.001$ ); and was willing to collaborate with people of diverse backgrounds and interests (students: 68.6 percent vs. alumni: 52.2 percent; $p<.001$ ). However, while 55.9 percent of the alumni reported treating patients with disabilities, 46.8 percent of the students indicated that they planned to do so in the future $(\mathrm{p}<.001)$. In addition, a higher percentage of alumni indicated that they treated patients from all socioeconomic backgrounds compared to the percentage of students who intended to treat these patients (alumni: 60.2 percent vs. students: 55.1 percent; $\mathrm{p}<.001)$.

We also examined the practice patterns of the alumni: 74.8 percent reported having no Medicaid patients, and 9.7 percent reported that more than 10 percent of their patients were covered by Medicaid. Approximately 10 percent of the practicing dentists had no African American patients, 15.5 percent had no Asian American patients, 14.6 percent had no Hispanic patients, and 56.2 percent had no Native American patients in their practices. In addition, of those dentists who reported that they had patients from these ethnic backgrounds, 70.8 percent reported that they had fewer than 10 percent African American patients, 87.1 percent that they had fewer than 10 percent Asian American patients, and 82.2 percent that they had fewer than 10 percent Hispanic patients in their practices.

The second objective was to determine how well dental students and dental alumni thought their dental education had prepared them to treat underserved patients. As can be seen in Table 2, the majority of dental students felt that their dental school experience prepared them well to become aware of problems related to oral health ( 80.2 percent) and to treat patients from different ethnic/racial groups (72.9 percent), from socioeconomically disadvantaged backgrounds (68.6 percent), and in different types of communities (68.3 percent). However, only 41.3 percent of the students felt that their dental education had prepared them well to treat patients with disabilities.

Compared to the students' responses, the alumni responses were less positive concerning how well their dental education had prepared them for treating patients from socioeconomically disadvantaged backgrounds (alumni: 38.4 percent versus students: 68.6 percent; $p<.001)$, treating patients from different ethnic/racial groups (alumni: 55.6 percent versus students: 72.9 percent; $\mathrm{p}<.001$ ), treating patients in different types of communities (alumni: 50.4 percent versus students: 65.8 percent; $p<.001$ ), gaining insights into the barriers to oral health care (alumni: 31.8 percent versus students: 65.2 percent; $\mathrm{p}<.001$ ), and becoming aware of problems related to oral health (alumni: 57.9 percent versus students: 80.2 percent; $p<.001)$. Approximately 35 percent of dental alumni, versus 41 percent of dental students, felt that their dental education had prepared them well for treating patients with disabilities $(\mathrm{p}<.001)$.

The third objective was to determine the effect of dental education on attitudes and behavior concerning providing care for underserved patients. As shown in Table 3, students' and alumni attitudes concerning treating underserved patients significantly correlated with the degree to which they perceived they had been well prepared by their dental education for their professional life $(r=.29 ; \mathrm{p}<.001)$; for treating patients from socioeconomically disadvantaged backgrounds $(\mathrm{r}=.24 ; \mathrm{p}<.001)$; for treating patients from different ethnic/racial groups $(\mathrm{r}=.24$; $\mathrm{p}<.001$ ); for treating patients in different types of communities $(r=.23 ; \mathrm{p}<.001)$; for gaining insights into the barriers to oral health care $(r=.19 ; \mathrm{p}<.001)$; and for becoming aware of problems related to oral health $(\mathrm{r}=.23 ; \mathrm{p}<.001)$. In addition, student and alumni attitudes concerning making a difference in the lives of others significantly correlated with the degree to which they perceived that they had been well prepared by their dental education for their professional life $(\mathrm{r}=.26 ; \mathrm{p}<.001)$; to treat patients from socioeconomically disadvantaged backgrounds $(\mathrm{r}=.20 ; \mathrm{p}<.001)$; to treat patients from different ethnic/racial groups $(r=.19 ; \mathrm{p}<.001)$; to treat patients in different types of communities $(r=.20 ; \mathrm{p}<.001)$; to 
Table 2. Frequencies/percentages of student and alumni evaluations of the quality of their dental education concerning treating underserved patients

\begin{tabular}{|c|c|c|c|c|c|c|}
\hline $\begin{array}{l}\text { My dental school experience } \\
\text { Students: prepares me well } \\
\text { Dentists: prepared me well }\end{array}$ & & Disagree* & Neutral** & Agree*** & $\mathrm{p}$ & mean \\
\hline \multirow[t]{2}{*}{ for my professional life. } & Students & $\begin{array}{l}14 \\
4.3 \%\end{array}$ & $\begin{array}{l}85 \\
26.3 \%\end{array}$ & $\begin{array}{l}224 \\
69.3 \%\end{array}$ & .028 & 3.81 \\
\hline & Dentists & $\begin{array}{l}19 \\
8.2 \%\end{array}$ & $\begin{array}{l}75 \\
32.3 \%\end{array}$ & $\begin{array}{l}138 \\
59.5 \%\end{array}$ & & $\begin{array}{l}3.69 \\
(.110)\end{array}$ \\
\hline \multirow[t]{2}{*}{$\begin{array}{l}\text { to treat patients from socioeconomically } \\
\text { disadvantaged backgrounds. }\end{array}$} & Students & $\begin{array}{l}10 \\
3.1 \%\end{array}$ & $\begin{array}{l}91 \\
28.3 \%\end{array}$ & $\begin{array}{l}221 \\
68.6 \%\end{array}$ & .000 & 3.83 \\
\hline & Dentists & $\begin{array}{l}48 \\
20.6 \%\end{array}$ & $\begin{array}{l}95 \\
40.9 \%\end{array}$ & $\begin{array}{l}89 \\
38.4 \%\end{array}$ & & $\begin{array}{l}3.22 \\
(.000)\end{array}$ \\
\hline \multirow[t]{2}{*}{$\begin{array}{l}\text { to treat patients from different } \\
\text { ethnic/racial groups. }\end{array}$} & Students & $\begin{array}{l}10 \\
3.1 \%\end{array}$ & $\begin{array}{l}77 \\
24.0 \%\end{array}$ & $\begin{array}{l}234 \\
72.9 \%\end{array}$ & .000 & 3.88 \\
\hline & Dentists & $\begin{array}{l}31 \\
13.4 \%\end{array}$ & $\begin{array}{l}72 \\
31.0 \%\end{array}$ & $\begin{array}{l}129 \\
55.6 \%\end{array}$ & & $\begin{array}{l}3.55 \\
(.000)\end{array}$ \\
\hline \multirow[t]{2}{*}{ to treat patients with disabilities. } & Students & $\begin{array}{l}55 \\
17.2 \%\end{array}$ & $\begin{aligned} 133 \\
41.6 \%\end{aligned}$ & $\begin{array}{r}132 \\
41.3 \%\end{array}$ & .000 & 3.32 \\
\hline & Dentists & $\begin{array}{l}83 \\
35.7 \%\end{array}$ & $\begin{array}{l}68 \\
29.3 \%\end{array}$ & $\begin{array}{l}81 \\
34.9 \%\end{array}$ & & $\begin{array}{l}2.98 \\
(.000)\end{array}$ \\
\hline \multirow[t]{2}{*}{$\begin{array}{l}\text { to treat patients in different types of } \\
\text { communities. }\end{array}$} & Students & $\begin{array}{l}16 \\
5.0 \%\end{array}$ & $\begin{array}{l}94 \\
29.3 \%\end{array}$ & $\begin{array}{r}211 \\
65.8 \%\end{array}$ & .000 & 3.76 \\
\hline & Dentists & $\begin{array}{l}31 \\
13.3 \%\end{array}$ & $\begin{array}{l}84 \\
36.2 \%\end{array}$ & $\begin{array}{l}117 \\
50.4 \%\end{array}$ & & $\begin{array}{l}3.43 \\
(.000)\end{array}$ \\
\hline \multirow[t]{2}{*}{$\begin{array}{l}\text { to gain insights into the barriers to oral } \\
\text { health care. }\end{array}$} & Students & $\begin{array}{l}15 \\
4.7 \%\end{array}$ & $\begin{array}{l}97 \\
30.1 \%\end{array}$ & $\begin{array}{l}210 \\
65.2 \%\end{array}$ & .000 & 3.76 \\
\hline & Dentists & $\begin{array}{l}66 \\
28.4 \%\end{array}$ & $\begin{array}{l}93 \\
39.9 \%\end{array}$ & $\begin{array}{l}74 \\
31.8 \%\end{array}$ & & $\begin{array}{l}3.05 \\
(.000)\end{array}$ \\
\hline \multirow[t]{2}{*}{$\begin{array}{l}\text { to become aware of problems related } \\
\text { to oral health. }\end{array}$} & Students & $\begin{array}{l}5 \\
1.5 \%\end{array}$ & $\begin{array}{c}59 \\
18.3 \% 80.2 \%\end{array}$ & 259 & .000 & 4.04 \\
\hline & Dentists & $\begin{array}{l}25 \\
10.8 \%\end{array}$ & $\begin{array}{l}73 \\
31.3 \%\end{array}$ & $\begin{array}{r}135 \\
57.9 \%\end{array}$ & & $\begin{array}{l}3.64 \\
(.000)\end{array}$ \\
\hline \multicolumn{7}{|c|}{$\begin{array}{l}\text { The answers were given on a 5-point answer scale with } 1 \text { being "disagree strongly" and } 5 \text { being "agree strongly." } \\
\text { *The frequencies of answers of the respondents who answered with " } 1 \text { " or " } 2 \text { " were summed up in the column "Disagree." } \\
\text { **The frequencies of answers of the respondents who responded with " } 3 \text { " are presented in the column entitled "Neutral." } \\
\text { ***The frequencies of answers of the respondents who answered with " } 4 \text { " or "5" are presented in the column entitled } \\
\text { "Agree." }\end{array}$} \\
\hline
\end{tabular}

gain insights into the barriers to oral health care $(\mathrm{r}=.16 ; \mathrm{p}<.001)$; and to become aware of problems related to oral health $(\mathrm{r}=.23 ; \mathrm{p}<.001)$. Furthermore, student and alumni attitudes concerning interacting with patients from different backgrounds significantly correlated with the degree to which they perceived that they had been well prepared by their dental education for their professional life $(\mathrm{r}=.28$; $\mathrm{p}<.001)$; to treat patients from socioeconomically disadvantaged backgrounds $(\mathrm{r}=.20 ; \mathrm{p}<.001)$; to treat patients from different ethnic/racial groups $(\mathrm{r}=.19$; $\mathrm{p}<.001)$; to treat patients in different types of communities $(\mathrm{r}=.21 ; \mathrm{p}<.001)$; to gain insights into the barriers to oral health care $(\mathrm{r}=.25 ; \mathrm{p}<.001)$; and to become aware of problems related to oral health $(\mathrm{r}=.25 ; \mathrm{p}<.001)$. In summary, the better prepared the students and alumni thought they were for providing care for underserved patients, the more positive their attitudes were.

As can be seen in Table 4, student and alumni perceptions of their dental education and their professional intentions and actual behavior correlated 
Table 3. Correlations between student and alumni evaluations of their dental education and their professional attitudes

Dental school prepared me well

I like to treat patients.

for my professional life.

to treat patients

- from different socioeconomic backgrounds.

- from different ethnic/racial backgrounds.

- with disabilities.

- in different types of communities.

to gain insights into the barriers to oral health care.

to become aware of problems related to oral health.

.29
$\mathrm{p}<.001$

.24

$\mathrm{p}<.001$

.24

$\mathrm{p}<.001$

.14

$\mathrm{p}=.23$

.23

$\mathrm{p}<.001$

.19

$\mathrm{p}<.001$

.23

$\mathrm{p}<.001$
I want to make a difference in the lives of others.

$\begin{array}{cc}.26 & .28 \\ \mathrm{p}<.001 & \mathrm{p}<.001\end{array}$

I like to treat patients from different backgrounds.

$.20 \quad .20$

$\mathrm{p}<.001 \quad \mathrm{p}<.001$

$.19 \quad .19$

$\mathrm{p}<.001 \quad \mathrm{p}<.001$

$.12 \quad .09$

$\mathrm{p}=.004 \quad \mathrm{p}=.028$

$.20 \quad .21$

$\mathrm{p}<.001 \quad \mathrm{p}<.001$

$.16 \quad .25$

$\mathrm{p}<.001 \quad \mathrm{p}<.001$

$.23-.25$

$\mathrm{p}<.001 \quad \mathrm{p}<.001$

Table 4. Correlations between student and alumni perceptions of their dental education and their professional behavior/behavioral intentions

Dental school prepared me well

\begin{tabular}{|c|c|c|c|c|c|c|c|}
\hline & $\begin{array}{l}\text { for my } \\
\text { professional } \\
\text { life. }\end{array}$ & $\begin{array}{l}\text { to treat } \\
\text { patients from } \\
\text { different } \\
\text { socioeconomic } \\
\text { backgrounds. }\end{array}$ & $\begin{array}{l}\text { to treat } \\
\text { patients from } \\
\text { different } \\
\text { ethnic/racial } \\
\text { groups. }\end{array}$ & $\begin{array}{c}\text { to treat } \\
\text { patients with } \\
\text { disabilities. }\end{array}$ & $\begin{array}{l}\text { to treat } \\
\text { patients in } \\
\text { different } \\
\text { types of } \\
\text { communities. }\end{array}$ & $\begin{array}{c}\text { to gain } \\
\text { insights into } \\
\text { the barriers } \\
\text { to oral health } \\
\text { care. }\end{array}$ & $\begin{array}{l}\text { to become } \\
\text { aware of } \\
\text { problems } \\
\text { related to } \\
\text { oral health. }\end{array}$ \\
\hline \multicolumn{8}{|l|}{ I treat } \\
\hline $\begin{array}{l}\text { - a diverse patient } \\
\text { population. }\end{array}$ & $\begin{array}{c}.17 \\
p<.001\end{array}$ & $\begin{array}{c}.13 \\
p=.003\end{array}$ & $\begin{array}{c}.13 \\
p=.003\end{array}$ & $\begin{array}{c}.07 \\
p=.128\end{array}$ & $\begin{array}{c}.12 \\
p=.005\end{array}$ & $\begin{array}{c}.13 \\
p=.003\end{array}$ & $\begin{array}{c}.15 \\
p=.001\end{array}$ \\
\hline $\begin{array}{l}\text { - patients from all } \\
\text { socioeconomic } \\
\text { backgrounds. }\end{array}$ & $\begin{array}{c}.11 \\
p=.010\end{array}$ & $\begin{array}{c}.08 \\
p=.072\end{array}$ & $\begin{array}{c}.14 \\
p=.001\end{array}$ & $\begin{array}{c}.14 \\
p=.001\end{array}$ & $\begin{array}{c}.12 \\
p=.004\end{array}$ & $\begin{array}{c}.13 \\
p=.002\end{array}$ & $\begin{array}{c}.11 \\
p=.009\end{array}$ \\
\hline $\begin{array}{l}\text { - patients with } \\
\text { disabilities. }\end{array}$ & $\begin{array}{c}.04 \\
p=.329\end{array}$ & $\begin{array}{c}.09 \\
p=.036\end{array}$ & $\begin{array}{c}.11 \\
p=.013\end{array}$ & $\begin{array}{c}.22 \\
p<.001\end{array}$ & $\begin{array}{c}.13 \\
p=.003\end{array}$ & $\begin{array}{c}.16 \\
p<.001\end{array}$ & $\begin{array}{c}.14 \\
p=.001\end{array}$ \\
\hline - underserved patients. & $\begin{array}{c}.10 \\
p=.015\end{array}$ & $\begin{array}{c}.15 \\
\mathrm{p}<.001\end{array}$ & $\begin{array}{c}.09 \\
p=.031\end{array}$ & $\begin{array}{c}.12 \\
p=.007\end{array}$ & $\begin{array}{c}.10 \\
p=.023\end{array}$ & $\begin{array}{c}.14 \\
p=.001\end{array}$ & $\begin{array}{c}.16 \\
\mathrm{p}<.001\end{array}$ \\
\hline $\begin{array}{l}\text { I volunteer services to } \\
\text { underserved patients. }\end{array}$ & $\begin{array}{c}.14 \\
p=.001\end{array}$ & $\begin{array}{c}.14 \\
p=.001\end{array}$ & $\begin{array}{c}.12 \\
p=.004\end{array}$ & $\begin{array}{c}.12 \\
p=.006\end{array}$ & $\begin{array}{c}.14 \\
p=.001\end{array}$ & $\begin{array}{c}.20 \\
\mathrm{p}<.001\end{array}$ & $\begin{array}{c}.18 \\
\mathrm{p}<.001\end{array}$ \\
\hline $\begin{array}{l}\text { I address community } \\
\text { needs. }\end{array}$ & $\begin{array}{c}.18 \\
\mathrm{p}<.001\end{array}$ & $\begin{array}{c}.23 \\
\mathrm{p}<.001\end{array}$ & $\begin{array}{c}.18 \\
\mathrm{p}<.001\end{array}$ & $\begin{array}{c}.15 \\
\mathrm{p}<.001\end{array}$ & $\begin{array}{c}.19 \\
\mathrm{p}<.001\end{array}$ & $\begin{array}{c}.24 \\
\mathrm{p}<.001\end{array}$ & $\begin{array}{c}.25 \\
\mathrm{p}<.001\end{array}$ \\
\hline $\begin{array}{l}\text { I make a positive } \\
\text { difference on public } \\
\text { issues. }\end{array}$ & $\begin{array}{c}.14 \\
p=.001\end{array}$ & $\begin{array}{c}.22 \\
p<.001\end{array}$ & $\begin{array}{c}.21 \\
\mathrm{p}<.001\end{array}$ & $\begin{array}{c}.19 \\
\mathrm{p}<.001\end{array}$ & $\begin{array}{c}.22 \\
p<.001\end{array}$ & $\begin{array}{c}.23 \\
p<.001\end{array}$ & $\begin{array}{c}.20 \\
\mathrm{p}<.001\end{array}$ \\
\hline $\begin{array}{l}\text { I like the opportunity } \\
\text { to collaborate with } \\
\text { people of diverse } \\
\text { backgrounds and } \\
\text { interests. }\end{array}$ & $\begin{array}{c}.16 \\
\mathrm{p}<.001\end{array}$ & $\begin{array}{c}.18 \\
\mathrm{p}<.001\end{array}$ & $\begin{array}{c}.13 \\
p=.003\end{array}$ & $\begin{array}{c}.10 \\
p=.017\end{array}$ & $\begin{array}{c}.15 \\
p=.001\end{array}$ & $\begin{array}{c}.20 \\
p<.001\end{array}$ & $\begin{array}{c}.17 \\
p<.001\end{array}$ \\
\hline
\end{tabular}


significantly. The behavioral intentions/actual behavior of students and alumni concerning providing care for diverse patients significantly correlated with all but one indicator of educational preparedness. There was no significant relationship between the students' intentions/alumni behavior and their level of educational preparedness for treating patients with disabilities. Student and alumni behavioral intentions/behavior concerning treating patients from all socioeconomic backgrounds significantly correlated with all educational indicators. Student and alumni behavioral intentions/behavior concerning treating underserved patients significantly correlated with the degree to which they perceived themselves to be well prepared by their dental education for their professional life $(\mathrm{r}=.10 ; \mathrm{p}=.015)$; to treat patients from socioeconomically disadvantaged backgrounds $(\mathrm{r}=.15$; $\mathrm{p}<.001)$; to treat patients from different ethnic/racial groups $(\mathrm{r}=.09 ; \mathrm{p}=.031)$; to treat patients in different types of communities $(r=.10 ; p=.023)$; to gain insights into the barriers to oral health care $(r=.14 ; \mathrm{p}=.001)$; and to become aware of problems related to oral health $(\mathrm{r}=.16 ; \mathrm{p}<.001)$. The behavioral intentions/ behavior of students and alumni concerning volunteering their services to underserved patients as well as using their abilities to address community needs and making a positive difference on public issues significantly correlated with all indicators of educational preparedness. The behavioral intentions/behavior of students and alumni concerning willingness to collaborate with people of diverse backgrounds and interests significantly correlated with the degree to which they perceived themselves to be well prepared by their dental education for their professional life $(\mathrm{r}=.16 ; \mathrm{p}<.001)$; to treat patients from socioeconomically disadvantaged backgrounds $(\mathrm{r}=.18 ; \mathrm{p}<.001)$; to treat patients from different ethnic/racial groups $(r=.13 ; p=.003)$; to treat patients in different types of communities $(\mathrm{r}=.15 ; \mathrm{p}=.001)$; to gain insights into the barriers to oral health care $(\mathrm{r}=.20 ; \mathrm{p}<.001)$; and to become aware of problems related to oral health $(\mathrm{r}=.17 ; \mathrm{p}<.001)$.

The influence of the year of alumni graduation from dental school and their ethnicity/race was also explored. The year of alumni graduation correlated significantly with professional behavior/behavioral intentions. The data showed that the more recent the graduation year was, the more likely the respondents were to treat a diverse patient population $(\mathrm{r}=-.098$; $\mathrm{p}=.022)$, underserved patients $(\mathrm{r}=-.189 ; \mathrm{p}<.001)$, volunteer treatment to underserved patients $(\mathrm{r}=-.312$; $\mathrm{p}<.001)$, address community needs $(\mathrm{r}=-.352 ; \mathrm{p}<.001)$, make a positive difference on public issues $(\mathrm{r}=-.350$; $\mathrm{p}<.001$ ), and collaborate with people of diverse backgrounds and interests $(\mathrm{r}=-.194 ; \mathrm{p}<.001)$.

Exploring the role of providers' ethnicity/race is challenging due to the small number of African American respondents. However, it might be worthwhile to mention that the data showed that African American alumni treated on average significantly more African American patients than white alumni (39.3 percent vs. 10.2 percent; $p<.001$ ). African American dental students agreed more strongly with a statement that they will treat diverse patients in their future professional lives than white students (on 5-point scale: 3.96 vs. $3.44 ; p=.008$ ).

\section{Discussion}

The purpose of this study was to explore a) dental students' intentions and dentists' behavior concerning providing care for underserved patients, b) their perceptions of their education concerning the treatment of these patients, and c) the relationship between the perceived quality of their dental education and their attitudes and behavior concerning providing care for underserved patients.

The findings for dental students' intentions and alumni behavior showed that a relatively higher percentage of students indicated an intention to provide care for underserved patient groups compared to the percentage of alumni who actually treated these patients. The only exception to this general finding was the degree to which students and providers responded to the statement concerning patients with disabilities. This finding may reflect a lack of education concerning the prevalence rates of various disabilities in the United States (see also Dao et al. ${ }^{10}$ ).

While the more positive responses of the students compared to the alumni were quite encouraging, it should be made clear that every single graduating dental student should be willing to treat diverse patients. The finding that only 46.8 percent of students plan to treat patients with disabilities and that only 50 percent of students plan to treat underserved patients should be a wake-up call for every dental school in the country. In addition, when these responses are considered in the context of the shifting demographics in the United States, the necessity for action becomes even more striking. Twelve percent of the students, for example, disagreed with the statement 
that they will treat a diverse patient population in their future professional life, and 32.8 percent responded in a neutral fashion to this statement. Considering the shifting demographics in the United States, these percentages of responses should alert dental educators to the lack of awareness in a large group of dental students concerning the racial and ethnic composition of the U.S. population in the future.

Overall, the students' responses concerning their civic responsibilities were more positive than the practitioners' responses. The students clearly valued giving back to their respective communities more and held more idealistic values than the alumni. One possible reason for this finding could be that the alumni changed their behavior as a result of being faced with the economic consequences of treating larger numbers of patients with disabilities or treating patients from lower socioeconomic groups with less capacity to pay for services or patients with lower insurance coverage. While this factor may be significant for some providers, research has demonstrated that it definitely is not a determining factor for all providers. In particular, providers from underrepresented minority backgrounds and/or with personal experiences concerning a lack of care were more likely to say that they intended/actually served underserved patients, ${ }^{16}$ and dentists from underrepresented minority backgrounds were more likely to provide care to populations of patients from their own ethnic group. In 1999, African American and Hispanic dentists reported that 61.8 percent and 45 percent, respectively, of their practices were comprised of members of their own ethnic group. ${ }^{17}$ In addition, studies found that African American and Hispanic physicians practice in communities with a higher percentage of patients from their racial/ethnic group. African American physicians treated more Medicaid patients, and Hispanic physicians treated more uninsured patients than other physicians. ${ }^{18}$ It might be worthwhile to consider these findings in the dental school admission process.

The dental students' more positive responses concerning their behavioral intentions to treat underserved patients when compared with the practitioners' responses plus the striking relationships between the year of graduation and the responses to the statements concerning professional behavior/ behavioral intentions could possibly be interpreted as positive indicators for future change. It was quite encouraging to find that alumni who had graduated in more recent years and the dental student cohorts were more likely to intend/to treat underserved pa- tients, volunteer treatment to underserved patients, address community needs, make a positive difference on public issues, and collaborate with people of diverse backgrounds and interests compared to the more senior alumni.

The results concerning dental students' and practicing dentists' perceptions of the quality of their dental education for preparing them to treat underserved patients indicate that the students felt better prepared than the alumni. This finding is encouraging, but the data clearly showed that there is room for improvement. In addition, it is possible to conclude that the alumni felt they were less well prepared in comparison to the students because the students did not yet know exactly what they needed to know once they were actually practicing dentistry.

The findings concerning the relationship between the quality of dental education concerning providing care for underserved patients and the respondents' attitudes and behavior about this issue are consistent with previous research. Seale and Casamassimo $^{19}$ concluded that dentists' willingness to treat children and special populations depended on the intensity of their educational experiences. Dao et al. ${ }^{10}$ showed the same relationship for treating special needs patients. The results of our study showed that the level of preparedness was correlated with the students' and the providers' attitudes and behavior concerning providing care for underserved patients.

Factors that should be considered when reflecting on how to adequately prepare future providers include reconsidering the activities that take place during the dental education process such as the degree of exposure to underserved patients in the didactic courses, during the clinical training, and during community service activities. ${ }^{20}$ For example, more frequent exposure of students to underserved patient populations during dental school correlated significantly with an increased willingness among dentists to treat underserved patients. ${ }^{21,22}$

In this context, it might be worthwhile to consider dental school-community partnerships. Some studies have explored institutional barriers that may prevent organizations from integrating and providing desperately needed oral health care. Although the main identified problem was resources, referral partnerships with dental schools and outside dentists were identified as a barrier. ${ }^{23}$ Dental schools should consider new strategies such as exposing more dental students and residents to community health centers, including more public dental health material in dental school curricula, and strengthening ties between 
inner-city or rural practices and academic health centers. Innovative ways to recruit and educate dental students about underserved patients must be sought (see, for example, Gates et al. ${ }^{24}$ ).

This study was limited by the fact that the data were cross-sectional. Cross-sectional data do not provide an opportunity to assess the complex factors that shape students'/providers' attitudes and behaviors over time. However, the comparison of these cohorts shows the differences in the students' and providers' perspectives and could thus encourage future research to explore the factors that may be involved in creating these changes.

A second limitation is the fact that the data were collected in one single midwestern dental school. In addition, only five alumni classes dating back to 1980 were surveyed. However, despite the fact that the data were collected in only one dental school, the outcomes clearly showed the important role that dental education can play in preparing providers who care for underserved patients. The results thus support the statement made in the report of the ADEA President's Commission on Access that the "academic dental institutions, as the source of oral health professionals, have a distinct responsibility to educate dental and allied dental professionals who are competent to care for the changing needs of our society." 25

Given this mandate and the clear finding that dental education affects future providers' attitudes and professional behavior, major efforts should be made to educate dental students about the evolving demographic profile of the U.S. population over the next thirty years, the importance of cultural differences among their future patients and the patient population in the United States, and how these differences affect access to care and the process of delivering optimal care to all patients. Dental schools need to incorporate material about social justice, civic responsibilities, and cross-cultural differences into their curricula throughout the four years of dental school. Dental schools need to develop opportunities for their students to gain a better understanding of diverse community settings and how to practice effectively in such environments. Examples of how students could be educated more inclusively about treating patients from different backgrounds can be found on the Pipeline, Profession, and Practice: Community-Based Dental Education Program website (www.dentalpipeline.org) (see also information about curricular efforts made by the University of Pennsylvania School of Dental Medicine ${ }^{26}$ ).
In conclusion, these data showed that dental education concerning preparing future providers for serving underserved patients can and has to be improved. The finding that the level of preparedness was correlated with the providers' attitudes as well as their actual behaviors/behavioral intentions should alert dental educators to the fact that they play an important role in reducing oral health and access to care disparities in the United States. It is important that the leaders of dental education institutions understand the impact of education on dentists' decisions to treat underserved patients and that they implement curriculum changes that place a greater emphasis on educating their students about these matters. These changes will greatly contribute to more effective recruitment of future providers interested in reducing health care disparities and to educating dental professionals who will be willing to care for underserved patients - which ultimately should lead to a reduction in existing oral health disparities.

\section{Acknowledgments}

We are grateful for the support provided to this study by an AADR Student Research Fellowship (2004) to the first author. We also want to thank Brittany Williams for her help with this study.

\section{REFERENCES}

1. U.S. Department of Health and Human Services. Oral health in America: a report of the surgeon general. Rockville, MD: U.S. Department of Health and Human Services, National Institute of Dental and Craniofacial Research, National Institutes of Health, 2000.

2. Mueller CD, Schur CL, Paramore LC. Access to dental care in the United States. J Am Dent Assoc 1998; 129(April):429-37.

3. Sullivan Commission. Missing persons: minorities in the health professions. Atlanta: The Sullivan Commission, 2004.

4. Noonan AS, Evans CA. The need for diversity in the health professions. J Dent Educ 2003;67(9):1030-3.

5. Terrell C, Beaudreau J. 3000 by 2000 and beyond: next steps for promoting diversity in the health professions. J Dent Educ 2003;67(9):1048-52.

6. Shortage of minority dentists threatens dental health of underserved. Dent Today 2001;20(4):36.

7. Giles DE, Eyler J. The impact of a college community service laboratory on students' personal, social, and cognitive outcomes. J Adolesc 1994;17:327-9.

8. Fenton SJ. People with disabilities need more than lip service. Spec Care Dent 1999;19:198-9.

9. Romer M, Dougherty N, Amores-Lafleur E. Predoctoral education in special care dentistry. J Dent Child 1999; $66: 132-5$. 
10. Dao LP, Zwetchkenbaum S, Inglehart MR. General dentists and special needs patients: does dental education matter? J Dent Educ 2005;69(10):1107-15.

11. O Donnell D. Use of the SADP for measurement of attitudes of Chinese dental students and dental surgery assistants toward disabled persons. Spec Care Dent 1993; 13(2):81-5

12. Novak KF, Whitehead AW, Close JM, Kaplan AL. Students' perceived importance of diversity exposure and training in dental education. J Dent Educ 2004;68(3):355-60.

13. Li LB, Williams SD, Scammon DL. Practicing with the urban underserved. Arch Fam Med 1995;4(2):124-34.

14. Mofidi M, Konrad TR, Porterfield DS, Niska R, Wells B. Provision of care to the underserved populations by National Health Service Corps alumni dentists. J Public Health Dent 2002;62(2):102-8.

15. Burtner AP, Dicks JL. Providing oral health care to individuals with severe disabilities residing in the community. Spec Care Dent 1994;14(5):188-93.

16. Osborne PB, Haubenreich JE. Underserved region recruitment and return to practice: a thirty-year analysis. J Dent Educ 2003;67(5):505-8.

17. Brown LJ, Lazar V. Minority dentists: why do we need them? Closing the gap. Washington, DC: U.S. Department of Health and Human Services, Office of Minority Health, July 6-7, 1999.

18. Komaromy M, Grumbach K, Drake M, Vranizan K, Lurie $\mathrm{N}$, et al. The role of black and Hispanic physicians in providing health care for underserved populations. New Engl J Med 1996;334(20):1305-10.

19. Seale NS, Casamassimo PS. Access to dental care for children in the United States: a survey of general practitioners. J Am Dent Assoc 2003;134:1630-40.

20. Bailit H. Community-based clinical education programs. J Dent Educ 1999;63(12):867-72.

21. Damiano PC, Brown ER, Johnson JD, Scheetz JP. Factors affecting dentist participation in a state Medicaid program. J Dent Educ 1990;54(11):638-43.

22. Eklund SA, Pittman JL, Clark SJ. Michigan Medicaid's Healthy Kids dental program: an assessment of the first twelve months. J Am Dent Assoc 2003;134:1509-15.

23. Ramos-Rodriguez C, Schwartz MD, Rogers V, Alos V. Institutional barriers to providing oral health services for underserved populations in New York City. J Public Health Dent 2004;64(1):55-7.

24. Gates PE, Ganey JH, Brown MD. Building the minority faculty development pipeline. J Dent Educ 2003;67(9): 1034-8.

25. American Dental Education Association. Improving the oral health status of all Americans: roles and responsibilities of academic dental institutions. Washington, DC: American Dental Education Association, 2003.

26. Wadenya RO, Schwartz S, Lopez N, Fonseca R. Strategies for recruitment and retention of underrepresented minority students at the University of Pennsylvania School of Dental Medicine. J Dent Educ 2003;67(9):1039-41. 